\title{
Study of glacier meltwater resources in China
}

\author{
YANG ZHenNiang AND Hu XiAOgang \\ Lanzhou Institute of Glaciology and Geocryology, Academia Sinica, Lanzhou 730000, China
}

\begin{abstract}
Glacier meltwaters are an important component of surface water resources in western China. Based on glacier inventories, the total glacier area in China is $5.87 \times 10^{4} \mathrm{~km}^{2}$, the second largest for an Asian country. The total storage of water in glaciers is about $5132 \times 10^{3} \mathrm{~km}^{3}$, and the mean annual amount of glacier melt runoff is about $5.64 \times 10^{10} \mathrm{~m}^{3}$, or $2 \%$ of the total surface water resources of China. From the late 1950s to the present, measurements have been undertaken of about twenty mountain glaciers, and data on hydrology and meteorology obtained. The relationship between heat balance and glacier ablation has been investigated but for glacierized areas where there are no data, ice-melt runoff can be estimated from climatic data. Runoff of glacier meltwater decreases with increasing aridity of the climate. The impact of glacier meltwater on the regimes of mountain streams in different environments are described in this paper.
\end{abstract}

\section{INTRODUCTION}

Studies of glacier water resources for agricultural water supply were first carried out in 1958 in western China. Glaciers in the Qilian mountains were investigated and a field station was established between 1958 and 1962 at
Lauhugao Glacier in the western Qilian mountains. Later, a station was established at Ürümqi Glacier No. 1 in the eastern Tien Shan mountains (1959 to 1966, 1980 to present). This is the only station at which long-term multiscientific measurements have been achieved at an alpine glacier in China. Based on

Table 1. Basic characteristics of different types of glaciers in the mountainous areas of western China

Type of glacier

Continental Sub-continental Maritime

mean annual precipitation at ELA (mm)

mean annual air temp-

erature at ELA $\left({ }^{\circ} \mathrm{C}\right)$

temperature in

glaciers $\left({ }^{\circ} \mathrm{C}\right)$

glacier flow velocity $\left(\mathrm{m} \mathrm{a}^{-1}\right)$

glacier terminus

elevation $(\mathrm{m})$

period of glacier

ablation (d)

glacial meltwater runoff $(\mathrm{mm})$
300 to 700

-15.0 to -9.0

-5.0 to -9.0

about -4.0
-1.0 to -5.0

30 to 100

4000 to 5000

$\sim 150$

(May-September)

200 to 600 spread to forest

belt

$\sim 180$

(May-October)

$\sim 700$ to 1000
$>100$

1200 to 3000

0

2400 to 3000

$\sim 210$

(April-October)

$>1000$ 
hydrometeorological measurements at permanent and semi-permanent stations, and on glacier inventories, estimation of glacial water resources in China was carried out in the 1980s. This paper attempts to use the regional trend of specific discharge from glaciers to estimate such runoff where there are no direct measurements, and to describe the compensating effect of glaciers on runoff in mountain streams.

\section{GLACIERS IN CHINA}

Excluding the polar regions, glaciers cover $2.24 \times 10^{5} \mathrm{~km}^{2}$ of the Earth's surface. About $26 \%$ $\left(5.87 \times 10^{4} \mathrm{~km}^{2}\right)$ of their area is located in China. Thousands of small glaciers occur over an extensive area that spans about $2700 \mathrm{~km}$ from east to west $\left(103^{\circ} 45^{\prime}\right.$ to $\left.73^{\circ} 55^{\prime} \mathrm{E}\right)$, and about $2400 \mathrm{~km}$ from south to north $\left(27^{\circ}\right.$ to $49^{\circ} \mathrm{N}$ ). All are found in high mountains and plateaus in western China, and most are valley glaciers. The glaciers can be classified into three types, depending on climatic, thermal and physical characteristics. Most glaciers belong to the continental type, while sub-continental and maritime types occupy only a small area. The continental-type glaciers occur in arid and semi-arid climatic regions which experience lower air temperatures and receive less precipitation than the maritime-type glaciers which are located in areas with moist climate, with abundant precipitation nourishment and higher air temperatures. The flow velocity of continental-type glaciers, in general, is much lower than that of the maritime type (Shi and Xie, 1964; Shi and Li, 1981; Li and Zhen, 1982; Huang and Sun, 1982; Xie and Zhen, 1982; Ren, 1988) and the yield of glacier meltwater runoff from continental-type glaciers is much smaller than from maritime-type glaciers (Yang, 1991) (Table 1).

\section{GLACIER ABLATION}

\section{Heat sources for glacier melt}

The main heat source for glacier ablation is net radiation, accounting for 60.5 to $92.1 \%$ of the total budget. Sensible heat can contribute from 6.6 to $35 \%$. The latent heat is usually considered to be small (Zeng and Dong, 1966; Zeng and Kou, 1975; Xie and Cao, 1965). The composition of heat budgets has an obvious regional pattern. The radiation heat flux increases with increasing aridity, decreasing latitude and increasing altitude. For sensible heat, the opposite applies, because the influence of moist air from southeastern and southwestern monsoons becomes more important, and the percentage contribution of sensible heat increases (Table 2). Different glacier surface types (firn, ice-snow and debris-covered)

Table 2. The composition of heat balance in various glaciers during the ablation season

\begin{tabular}{|c|c|c|c|c|c|c|c|c|c|c|c|c|}
\hline \multirow[t]{3}{*}{ Source } & \multirow[t]{3}{*}{ Glacier name } & \multicolumn{2}{|c|}{ Location } & \multirow{3}{*}{$\begin{array}{l}\text { Elevation } \\
\mathrm{m}\end{array}$} & \multirow{3}{*}{$\begin{array}{l}\text { Ice sur- } \\
\text { face }\end{array}$} & \multirow[t]{3}{*}{ Period } & \multirow{2}{*}{\multicolumn{3}{|c|}{$\begin{array}{c}\text { Constitution of the total heat } \\
\text { input } \\
\%\end{array}$}} & \multicolumn{3}{|c|}{ Constitution of heat output } \\
\hline & & $\mathrm{E}$ & $\mathrm{N}$ & & & & & & & & $\%$ & \\
\hline & & & & & & & $\begin{array}{l}\text { Net radi- } \\
\quad \text { ation }\end{array}$ & $\begin{array}{c}\text { Sensible } \\
\text { heat }\end{array}$ & $\begin{array}{l}\text { Condensa- } \\
\text { tion }\end{array}$ & $\begin{array}{l}\text { Heat for } \\
\text { ablation }\end{array}$ & $\begin{array}{c}\text { Sensible } \\
\text { heat }\end{array}$ & $\begin{array}{l}\text { Evapor- } \\
\text { tion }\end{array}$ \\
\hline $\begin{array}{l}\text { Zeng and Dong, } \\
1966\end{array}$ & $\begin{array}{l}\text { Qieerganbulake, } \\
\text { Pamir, China }\end{array}$ & $75^{\circ}$ & $38^{\circ}$ & 4750 & firn & $\begin{array}{c}\text { July-August } \\
1960\end{array}$ & 92.1 & 7.9 & & 58.5 & & 41.5 \\
\hline $\begin{array}{l}\text { Zeng and Kou } \\
\text { Jouguam, } 1975\end{array}$ & $\begin{array}{l}\text { Rongbu, Himal- } \\
\text { aya, Tibet }\end{array}$ & $86^{\circ}$ & $28^{\circ}$ & 5440 & debris & May 1960 & 89.5 & 2.5 & 8.0 & 33.0 & 42.8 & 15.9 \\
\hline $\begin{array}{l}\text { Xie and Cao, } \\
1965\end{array}$ & $\begin{array}{l}\text { Ürümqi Glacier } \\
\text { No. 1, Tien Shan }\end{array}$ & $87^{\circ}$ & $43^{\circ}$ & 3820 & firn & $\begin{array}{c}\text { June-August } \\
1962\end{array}$ & t 84.4 & 10.3 & 5.3 & 88.1 & & 11.9 \\
\hline $\begin{array}{l}\text { Wang and } \\
\text { others, } 1982\end{array}$ & $\begin{array}{l}\text { Shuiguanhe } \\
\text { Glacier No. 4, } \\
\text { Qilian }\end{array}$ & $102^{\circ}$ & $37^{\circ}$ & 4200 ic & ce-snow & August 1963 & 82.7 & 14.3 & 3.0 & 90.5 & & 9.5 \\
\hline $\begin{array}{l}\text { Wang and } \\
\text { others, } 1982\end{array}$ & $\begin{array}{l}\text { Guxiang Glacier } \\
\text { No. 3, Nianqin- } \\
\text { tangula }\end{array}$ & $96^{\circ}$ & $30^{\circ}$ & $4400 \mathrm{i}$ & ice-snow & $\begin{array}{c}\text { July-August } \\
1965\end{array}$ & 63.0 & 26.4 & 10.6 & 96.9 & & 3.1 \\
\hline $\begin{array}{l}\text { Kou and Zhang, } \\
1985\end{array}$ & $\begin{array}{l}\text { Qiongtailan, } \\
\text { Tien Shan, China }\end{array}$ & $80^{\circ}$ & $42^{\circ}$ & 4000 & $\begin{array}{c}\text { ice } \\
\text { debris }\end{array}$ & July 1978 & $\begin{array}{l}59.0 \\
73.0\end{array}$ & $\begin{array}{l}36.0 \\
23.0\end{array}$ & $\begin{array}{l}5.0 \\
4.0\end{array}$ & $\begin{array}{l}82.0 \\
41.0\end{array}$ & 30.0 & $\begin{array}{l}18.9 \\
29.0\end{array}$ \\
\hline $\begin{array}{l}\text { Bai and Zhang, } \\
1980\end{array}$ & $\begin{array}{l}\text { Batura, } \\
\text { Karakoram, } \\
\text { Pakistan }\end{array}$ & $75^{\circ}$ & $37^{\circ}$ & 3368 & debris & $\begin{array}{c}\text { July-August } \\
1974\end{array}$ & 89.2 & 8.7 & 2.1 & 83.3 & 1.0 & 11.1 \\
\hline
\end{tabular}


influence heat budgets through different albedos (Zeng and others, 1984).

The relationship between glacier meltwater and radiation balance can be expressed as

$$
Q=\mathrm{a} Q_{\mathrm{B}}^{\mathrm{n}},
$$

where $Q$ is the discharge from an experimental plot of ice surface $\left(\mathrm{m}^{3} \mathrm{~s}^{-1}\right), Q_{\mathrm{B}}$ is the radiation balance value (MJ $\left.\mathrm{m}^{-2} \mathrm{~d}^{-1}\right), \mathrm{a}$ is an empirical coefficient and $\mathrm{n}$ is an empirical exponent.

\section{The relationship between ablation and air tem- perature}

Although Equation (1) provides a useful relationship for estimating glacier meltwater runoff, the value of $Q_{\mathrm{B}}$ is difficult to obtain. Air temperature is often used as an index of energy balance for establishing an empirical relationship to estimate ablation of ice. The synthetic empirical equation can be approximated as follows:

$$
A=\phi(T+4.0)^{2.7}
$$

where $A$ is glacier ablation rate $\left(\mathrm{mm} \mathrm{d}^{-1}\right), T$ is air temperature $\left({ }^{\circ} \mathrm{C}\right)$ at the median elevation of the glacier, and $\phi$ is a coefficient reflecting the influence of climatic conditions in different regions (Yang, 1981):

$$
\phi=0.382 b^{2}
$$

in which $b=Q_{\mathrm{B}} / Q_{\mathrm{T}}$, where $Q_{\mathrm{B}}$ is the radiation balance and $Q_{\mathrm{T}}$ the total heat received during the melt season. It is similar to the method of estimating glacier ablation at the equilibrium line, proposed by Khodakov (1975). Where there is no direct measurement of air temperature on the glacier surface, air temperature gradient can be used and an approximate relationship is:

$$
\begin{gathered}
T=T_{0}+H(\mathrm{~d} T / \mathrm{d} H)-J_{\mathrm{t}} \\
\log J_{\mathrm{t}}=0.281 \log L-0.07 .
\end{gathered}
$$

$T_{0}$ is the air temperature $\left({ }^{\circ} \mathrm{C}\right)$ at the meteorological station, $H$ is the altitude difference $(\mathrm{m})$ between the meteorological station and the median elevation of the glacier, $\mathrm{d} T / \mathrm{d} H$ is the air temperature gradient $\left({ }^{\circ} \mathrm{C} 100\right.$ $\left.\mathrm{m}^{-1}\right), J_{\mathrm{t}}$ allows for the increase of air temperature gradient with elevation (Khodakov, 1975) and $L$ is the glacier length $(\mathrm{km})$.

Some estimates of ablation shown in Equation (2) are in close agreement with the results of measurements from ablation stakes (Yang, 1991).

\section{GLACIER MELT RUNOFF}

\section{Characteristics of glacier melt runoff}

For more then six months, air temperatures in high mountain areas remain below $0^{\circ} \mathrm{C}$, until late spring or early summer, when they rise above $0^{\circ} \mathrm{C}$. Snow on the glacier surface begins to melt in late April or early May on continental-type glaciers, and in early April on maritime-type glaciers. The melt is weak, and the melwater is absorbed in the snow layers. During the cold nights, the meltwater is refrozen and surface runoff is arrested. As the season advances, the melt increases to sustain continuous runoff on the glacier surface, forming a network of channels. In small glaciers of the continental type, such as in Ürümqi Glacier No. 1, the meltwater moves along the major channels which enter mountain streams directly. However, in larger glaciers, or maritimetype glaciers, much of the meltwater disappears through cracks and moulins, to emerge from under the terminus in one or more large streams. This outflow is sometimes maintained even during winter (Yang, 1988). Quntailan Glacier in Tien Shan (subcontinental-type) and Gongga Glacier in Henduan Shan (maritime-type) are such examples.

Synchronous co-variation between air temperature and meltwater runoff is more significant in continentalthan maritime-type glaciers. Analysis shows the relationship between discharge and air temperature when there is no precipitation can be given as follows

$$
\begin{gathered}
Q=\alpha \exp (\beta T) \\
Q=\mathrm{a}+\mathrm{b} T+\mathrm{c} T^{2}
\end{gathered}
$$

where $Q$ is the glacier melt discharge $\left(\mathrm{m}^{3} \mathrm{~s}^{-1}\right), T$ is mean air temperature $\left({ }^{\circ} \mathrm{C}\right)$ on the glacier during the ice-melt period , and $\alpha, \beta, \mathrm{a}, \mathrm{b}$, and $\mathrm{c}$ are empirical coefficients (Kang, 1983; Hu and Li, 1989; Yang, 1988).

\section{The compensating effect of melt runoff}

Most mountain streams in western China receive glacier meltwater. The percentage of glacier melt in runoff increases with increasingly arid climate. For example, in the internal drainage rivers of the Heshi region, from east to west, the percentage of glacier melt in runoff increases from 4 to $32 \%$. During dry warm summer periods with scarce precipitation, large percentages of glacier meltwater augment low flow. When abundant precipitation with low air temperature occurs, generally it has a negative influence on glacier melt runoff. In streams dominated by glacier melt runoff, the coefficient of variation of mean annual runoff $\left(C_{v}=0.10\right.$ to 0.20$)$ is smaller than that of rain- or snow-fed streams $\left(C_{v}=0.20\right.$ to 0.45 ).

\section{GLACIER MELTWATER RESOURCES}

The main problem in estimating the amount of glacier meltwater runoff is the lack of hydrometeorological data. Specific runoff from glaciers $M_{\mathrm{g}}\left(1 \mathrm{~s}^{-1} \mathrm{~km}^{-2}\right)$ has been obtained from several glacierized areas in China. As it has an obvious regional regularity, $M_{\mathrm{g}}$ can be estimated from glacierized areas without direct measurement as follows:

$$
M_{\mathrm{g}}=K\left\{M_{\mathrm{g}_{0}}+\left[\mathrm{d} H_{0} \frac{\mathrm{d} T}{\mathrm{~d} H}+\mathrm{d} T^{\prime}\right] \frac{\mathrm{d} M_{\mathrm{g}}}{\mathrm{d} T}\right\},
$$

where $K$ is the modification coefficient of ablation area, $K=f_{\mathrm{g}} / f_{\mathrm{g} 0}, f_{\mathrm{g}}$ is the percentage of ablation area for the glacier where the specific runoff is to be determined, $f_{\mathrm{g}_{0}}$ is 
that for the glacier where the runoff $\left(M_{\mathrm{g}_{0}}\right)$ has been measured, $\mathrm{d} H_{0}$ is the difference in the elevation of the equilibrium lines between the two glaciers, $\mathrm{d} T / \mathrm{d} H$ is the air temperature lapse rate, usually equal to $0.65^{\circ} \mathrm{C}$ per $100 \mathrm{~m}, \mathrm{~d} T^{\prime}$ is the air temperature modification value owing to the climatic difference between two glaciers at the same elevation. $\mathrm{d} M_{\mathrm{g}} / \mathrm{d} T$ is the increment of $M_{\mathrm{g}}$ with air temperature, empirically found to be $5.01 \mathrm{~s}^{-1} \mathrm{~km}^{-2}$ per ${ }^{\circ} \mathrm{C}$.

For two glaciers located not only in the same climatic region, but also having similar equilibrium line altitudes, the equation reduces to

$$
M_{\mathrm{g}}=K\left(M \mathrm{~g}_{0}\right) .
$$

The difference in $M_{\mathrm{g}}$ is caused only by the difference in the percentage of ablation area.

Using Equation (8) the total volume of glacier meltwater $\left(\mathrm{m}^{3}\right)$ produced during the ablation season is

$$
W_{\mathrm{g}}=86.4 M_{\mathrm{g}} t F_{\mathrm{s}}
$$

where $t$ is the melt period, about 150 days for continentaltype glaciers, 180 days for subcontinental-type and 210 days for maritime-type glaciers. $F_{\mathrm{s}}$ is the glacier area $\left(\mathrm{km}^{2}\right)$.

The mean annual amount of glacier meltwater runoff in western China is estimated to be about $56.4 \mathrm{~km}^{3}$ or $5.64 \times 10^{10} \mathrm{~m}^{3}$ (Table 3). It is about $10 \%$ of the total amount of runoff from all sources in the four provinces in western China.

Table 3. Glacier areas and annual meltwater runoff

\begin{tabular}{|c|c|c|c|}
\hline 1 Altay & 293.20 & 3.85 & May-September \\
\hline 2 Tien Shan & 9196.00 & 95.92 & $\begin{array}{l}\text { May-September/ } \\
\text { October }\end{array}$ \\
\hline 3 Qilian & 1972.50 & 11.56 & May-September \\
\hline 4 Kulun & 12482.20 & 62.98 & May-September \\
\hline Pamir & 2992.85 & 17.05 & May-September \\
\hline 6 Karakoram & 4647.17 & 28.71 & May-September \\
\hline $\begin{array}{c}7 \text { Qiangtang } \\
\text { plateau }\end{array}$ & 3108.81 & 16.03 & May-September \\
\hline 8 Tanggula & 2082.00 & 16.33 & May-September \\
\hline 9 Gangdisi & 1667.75 & 8.88 & May-September \\
\hline $\begin{array}{l}10 \text { Nianqin- } \\
\text { tanggula }\end{array}$ & 7536.00 & 150.24 & April-October \\
\hline Hengduan & 1617.62 & 51.16 & April-October \\
\hline 2 Himalaya & 11055.00 & 100.71 & May-September \\
\hline Total & 58651.10 & 563.42 & \\
\hline
\end{tabular}

$\begin{array}{ccc}\text { No. Mountains } & \begin{array}{r}\text { Area of } \\ \text { glacier }\end{array} & \begin{array}{c}\text { Meltwater } \\ \text { runoff }\end{array} \\ & \mathrm{km}^{2} & 10^{8} \mathrm{~m}^{3}\end{array}$

\section{REFERENCES}

Bai Chongyuan and Zhang Jinhua. 1980. Some features of radiation and heat balance of Batura Glacier. Beijing, Science Press, 57-82.

$\mathrm{Hu}$ Xiaogang and Li Nianjie. 1989. A stochastic meltwater runoff model of Heigou Glacier No. 8 in the southern slope of Mt Bogda. 7. Glaciol. Geocryol., 11(3), 279-286. [In Chinese with English abstract.]

Huang Maohuan and Sun Zuozhe. 1982. Some flow characteristics of continental-type glaciers in China. 7 . Glaciol. Geocryol., 4(2), 35-45. [In Chinese with English abstract.]

Kang Ersi. 1983. Glacial meltwater runoff on north flank of $\mathrm{Mt} \mathrm{Bogda}$ in Tien Shan and its contribution to river flow. 7. Glaciol. Geocryol., 5(3), 113-122. [In Chinese with English abstract.]

Khodakov, V.G. 1975. Glaciers as water resource indicators of the glacial areas of the USSR. International Association of Hydrological Sciences Publication 104 (General Assembly of Moscow 1971 - Snow and Ice), 2229.

Kou Jouguam and Zhang Yongliang. 1985. Radiation heat balance and water vapour transfer in $\mathrm{Mt}$ Tuomuer district. In Glaciology and meteorology in Tuomuer mountain region. Ürümqi, Publishing House of Xinjiang, 120-142.

Li Jijun and Zhen Benxing. 1982. The characteristics of modern glaciers in Qinghai-Xizang Plateau. Bulletin of Glaciology and Geocryology (Glaciology). In Proceedings of the Symposium on Glaciology and Cryopedology held by the Geographical Society of China. Beijing, Science Press, 14-17. [In Chinese.]

Ren Binghui. 1988. Present variation of modern glaciers in China. In Shi Yafeng, ed. An introduction to the glaciers in China. Beijing, Science Press, 171-186. [In Chinese.]

Shi Yafeng and Li Jijun. 1981. Glaciological research of the Qinghai-Xizang Plateau in China. In Proceedings of the Symposium on Qinghai-Xizang Plateau. Vol. 2. Beijing, Science Press; New York, Gordon and Breach, 15891597.

Shi Yafeng and Xie Zichu. 1964. The basic characteristics of modern glaciers in China. 7. Geogr., 30(3), 183-208. [In Chinese.]

Wang Chunglung, Deng Yangxin and Zeng Xiangyin. 1982. Water and heat conditions of glacier development in Guxiang maritime glacier in Tibet. Lanzhou Institute of Glaciology and Geocryology. Academia Sinica. Memoirs 3, 82-90. [In Chinese.]

Xie Weirong and Cao Meishang. 1965. The preliminary result of measuring snow evaporation in Ürümqi Glacier No. 1, Tien Shan. In Shi Yafeng, ed. Research of Glaciers and Hydrology. Beijing, Science Press, 12-24. [In Chinese.]

Xie Zichu and Zhen Benxing. 1982. The distribution, features and variations of glaciers in China. Bulletin of Glaciology and Geocryology (Glaciology). In Proceedings of the Symposium on Glaciology and Cryopedology held by the Geographical Society of China. Beijing, Science Press, 13.

Yang Zhenniang. 1981. Basic characteristics of runoff in contemporary glaciated areas of China. Sci. Sin., Ser. B, 24(10), 1418-1430. 
Yang Zhenniang. 1988. Glacier melt runoff and its compensating effect on mountain streams of China. In Shi Yafeng, ed. An introduction to the glaciers in China. Beijing, Science Press, 187-202.

Yang Zhenniang, ed. 1991. Glacier water resources of China. Lanzhou, Science and Technology Publishing House of Gansu, 39-45. [In Chinese.]

Zeng Mingxian and Dong Guangrong. 1966. Radiation and heat balance during the glacier ablation period of Qieerganbulage Glacier of Muztagata. In Proceedings of the Arid Region Conference of the Geography Society of China. Beijing, Science Press, 97-100. [In Chinese.]
Zeng Qunzhu and Kou Youguan. 1975. Heat balance during glacier ablation in Rongbuk Glacier. In $A$ report of the 1966-68 Scientific Expedition to the Mt Qomolangma Region. Glaciology and Geomorphology. Beijing, Science Press, 52-64. [In Chinese.]

Zeng Qunzhu, Cao Meisheng and Feng Xuezhi. 1984. Study on spectral reflection characteristics of snow, ice and water of northwest China. Sci. Sin., Ser. B, 27(6), 647-656. [In Chinese.]

The accuracy of references in the text and in this list is the responsibility of the author/s, to whom queries should be addressed. 